\title{
The Relationship among Iranian EFL Teachers' Professional Identity, Self-Efficacy and Critical Thinking Skills*
}

\author{
La relación entre la identidad profesional de \\ los profesores iranís de inglés como lengua \\ extranjera, y sus habilidades de autoeficiencia \\ y pensamiento crítico
}

\section{Negar Moslemi}

She has received her MA in TEFL from Azad University, Sanandaj Branch (Iran). She has been teaching English language in different institutes for more than four years. Her current research interest is focused on teaching English as a foreign language. She has published a research paper in HOW journal. moslemi.negar@iausdj.ac.ir

\section{Parya Habibi}

She holds $\mathrm{BA}$ and an MA in TEFL from Azad University, Sanandaj Branch (Iran). Her research is focused on teaching English as a foreign language. She has published three research papers in international journals. She has also presented research papers in international conferences.

paryahabibi@iausdj.ac.ir

* Received: August 23, 2018. Accepted: January 21, 2019

How to cite this article (APA 6th Edition):

Moslemi, N., \& Habibi, P. (2019). The relationship among Iranian EFL teachers' professional identity, self-efficacy and critical thinking skills. HOW, 26(1), 107-128. https://doi. org/10.19183/how.26.1.483

This article is licensed under a Creative Commons Attribution-NonCommercial-NoDerivatives 4.0 International License. License Deed can be consulted at https://creativecommons.org/ licenses/by-nc-nd/4.0/ 


\section{Abstract}

Teachers' beliefs, attitudes, and identities have been considered as the main factors in improving their performance to enhance students' learning. The present study aimed to explore the relationship among Iranian EFL teachers' professional identity, their self-efficacy, and their critical thinking skills in their teaching process. To achieve the objective of the study, 75 EFL teachers participated in this study. Three instruments were used to collect the required data including professional identity, TEBS-Self questionnaires, and the Watson-Glaser Critical Thinking Appraisal test. The findings in the present study demonstrate that there was a strong positive relationship of the EFL teachers' professional identity between their self-efficacy and their critical thinking skills. The results of the ANOVA (analysis of variance models) test indicated that the EFL teachers' professional identity could predict their self-efficacy and their critical thinking skills.

Keywords: critical thinking skills, identity, professional identity, teachers' self-efficacy.

\section{Resumen}

Las creencias, actitudes e identidades de los profesores se han considerado como los aspectos principales en el mejoramiento de su desempeño al promover el aprendizaje de los estudiantes. El presente estudio busca explorar la relación entre la identidad profesional, la autoeficiencia, y las habilidades de pensamiento crítico en la enseñanza de inglés como lengua extranjera entre profesores iraníes de inglés. Para alcanzar este objetivo, 75 profesores iraníes de inglés participaron en el estudio. Se usaron tres instrumentos para la recolección de datos que incluyen los cuestionarios TEBS-Self y Watson-Glaser Critical Thinking Appraisal. Los resultados demuestran que hay una fuerte y positiva relación entre la identidad profesional de los profesores y su autoeficiencia y las habilidades de pensamiento crítico. Los resultados del test ANOVA indican que la identidad profesional de los profesores podría predecir su autoeficiencia y sus habilidades de pensamiento crítico.

Palabras clave: habilidades de pensamiento crítico, identidad, identidad profesional, autoeficiencia de los profesores. 
The Relationship among Iranian EFL Teachers' Professional Identity, Self-Efficacy and Critical Thinking Skills

\section{Introduction}

Teacher identity has come into view as a principal topic in educational research since the 1990s. Understanding identities is "the central factor in the quest to secure a meaningful education in a culturally diverse society" (Kearney, 2003 , p. 1). The role of teachers' perceptions, beliefs, identities, and efficacy in making an effective EFL instruction, in improving their performance to enhance students' learning can be helpful. Little (1995, p. 180) suggests that "language teachers are more likely to succeed in promoting learner autonomy if their own education has encouraged them to be autonomous." Morita (2004) believes that teacher identity tries to capture teachers' interpretation of themselves with relation to their appointment.

In recent years, teachers' beliefs, attitudes, and identities have been viewed as the main factors in their performance in the classroom. Many studies have been conducted in this respect (Borg, 2003; Farrell, 2008; Golombek \& Johnson, 2004; Nishino, 2009; Pintrich \& Schunk, 1995; Schwitzgebel, 2011; Woods, 1991) by using different techniques of examination and distinctive hypothetical models. The majority of identity studies have been conducted on teachers' professional identity. Beijaard, Meijer, and Verloop (2004) believe that research on teachers' professional identity focuses on the ways "teachers relate to other people, and the responsibilities, attitudes, and behaviors they adopt as well as the knowledge they use" (p. 125). In fact, more studies should be conducted in this area for researchers to develop true understanding of the factors which affect teachers' beliefs, identities, and students' achievement.

Teachers' professional identity and their sense of self-efficacy have drawn more attention recently. Bandura (1997) defined self-efficacy as "the conviction that one can successfully execute the behavior required to produce outcomes" (p. 193). Bandura (1986) refers to four sources of self-efficacy: 1) Mastery experience (individuals' achievements), 2) Vicarious experience (other individuals' achievements), 3) Persuasions (what others say), and 4) Psychological states (anxiety, stress, and fear). Rich, Lev, and Fischer (1996) describe teacher efficacy as "a teacher's general feeling that the education system is capable of fostering satisfactorily student academic achievement despite negative influences external to the teacher" (p. 1016). 
Negar Moslemi and

Parya Habibi

The third personal feature that has drawn more attention in the present study is teachers' critical thinking skills to make reasoned judgments that are logical and well thought out. Williams (2005) believes that "critical thinking is important in all academic disciplines within democratic education, but it is indispensable in the field of teacher education" (p. 164). According to Paul and Elder (2005), critical thinking is "that mode of thinking about any subject, content or problem in which the thinker improves the quality of his or her thinking by skillfully taking charge of the structures inherent in thinking and imposing intellectual standards upon them" (p. 1). According to McPeck (1981), the basic nature of critical thinking is the disposition and skill to become involved in an activity with reflective skepticism. Teachers' critical thinking skills, in the foreign language teaching process, influence learners' learning process.

Teachers' awareness of their identities, and their self-efficacy and critical thinking skills can be considered as important factors in their professional development. Nevertheless, little research exists regarding the relationship between teachers' professional identity and their self-efficacy. The general aim of this study is to explore the relationship among Iranian EFL teachers' professional identities, their efficacy and critical thinking skills in their teaching process. This goal is realized through the following research questions:

Q1. Is there any relationship between Iranian English language teachers' professional identity and their self-efficacy?

Q2. Does EFL teachers' professional identity significantly predict their self-efficacy?

Q3. Is there any relationship between Iranian English language teachers' professional identity and their critical thinking skills?

Q4. Does EFL teachers' professional identity significantly predict their critical thinking skills?

\section{Literature Review}

Teachers' identities and professional identity. Teaching EFL is influenced by a number of conflicts related to the teachers' personal, social, professional, economic, and political factors. Palmer (1998) asserted that "good teaching 
The Relationship among Iranian EFL Teachers' Professional Identity, Self-Efficacy and Critical Thinking Skills

cannot be reduced to technique; good teaching comes from the identity and integrity of the teacher" (p. 10). Teacher identity tries to comprehend teachers' definition of themselves with relation to their profession. Analyzing teacher identity leads to better perception of educational theories and practice (Morita, 2004). Little (1995, p. 179) refers to "genuinely successful teachers" as "autonomous in the sense of having a strong sense of personal responsibility for their teaching, exercising via continuous reflection and analysis the highest possible degree of affective and cognitive control of the teaching process, and exploiting the freedom that this confers." According to Smith, Walker, Fields, Brookins, and Seay (1999), individual identity has an outstanding control on how they perceive others, their self-esteem, self-confidence, aspirations, motivation, and effort lay out in various aspects of their lives.

Analyzing teacher identity leads to a better perception of educational theories and practice (Ghafar Samar, Kiany, Akbari \& Azimi, 2011). According to Ghafar Samar et al. (2011, p. 38), "Preference and/or tendency to work with the people in an institution, including colleagues, manager(s), and staff is regarded as an important factor of institutional identity." White and Parham (1990) defined identity as "the adoption of certain personal attitudes, feelings, characteristics, and behaviors and the identification with a larger group of people who share those characteristics" (p. 42). Identity studies then focused on different manifestations of identity formation by emphasizing social, cultural, religious, political, and psychological differences.

Beijaard et al. (2004) determined that teacher identity formation is (a) ongoing, (b) involves both person and context, (c) consists of sub-identities that must be harmonious, and (d) requires a level of agency by teachers. Giddens (2002, p. 53) refers to self-identity or personal identity as that which is "understood by the person in terms of his or her own biography."

One aspect of many English language teachers' personalities is professional identity. According to Farrell (2008, p. 2), teachers "collect data about their teaching, examine their attitudes, beliefs, assumptions, and teaching practices, and use the information obtained as a basis for critical reflection about teaching." Helleve, Flisher, Onya, Mukkoma, and Klepp (2009, p. 191) contend that "there will be different perceptions, understandings and values among those persons who have been given the task of delivering an [education] programme." 
Negar Moslemi and

Parya Habibi

Different studies have different definitions of professional identity. Brown (2001) identified qualities of professional language teachers by classifying his ideas into four categories: technical knowledge, pedagogical skills, interpersonal skills, and personal qualities. Ghafar Samar et al. (2011, p. 32) asserted that identity, as a nonspecific term, is characterized as the type of persons individuals see themselves as or are seen as in a specific setting, a self-built procedure which is adjusted by various elements. Teacher identity, similarly, defines teachers regarding their profession. Investigation on teacher identity results in great impacts in different educational aspects such as teacher commitment (Day \& $\mathrm{Gu}$, as cited in Ghafar Samar et al., 2011). It also leads to a better perception of educational theories and practice.

Teachers' self-efficacy. The other aspect of many English language teachers' personalities is their efficacy. Bandura (1997) has defined self-efficacy as, "beliefs in one's capability to organize and execute the courses required to manage prospective situations" (p. 2). Bandura (1997) also suggests three context levels at which self-efficacy can be assessed, including: a domain general level, a domain specific level, and a task level. These four main forms of influence are sources of self-efficacy including: (a) Demographic Variables such as age, area of certification, gender, grade(s) instructed, and so on (Pajares, 1996; Pintrich \& Schunk, 1995; Tschannen-Moran \& Hoy, 2001); (b) Performance Accomplishments refers to individual's successes to increase self-efficacy (Bandura, 1997); (c) Vicarious Experience refers to indirect experience such as imitation and observation (Bandura, 1997); (d) Verbal Persuasion or social persuasion refers to the positive or negative comments from other people (Bandura, 1997; Maddux, 1995).

Tschannen-Moran and Hoy (2007), in their study about the difference between the efficacy of novice and experienced practicing teachers, found that verbal persuasion significantly predicted novice teachers' sense of efficacy 112 because "teachers who are struggling in their early years in their careers tend to lean more heavily on the support of their colleagues" (p. 953). TschannenMoran et al. (1998, p. 233) define teachers' self-efficacy as a "teacher's belief in his/ her abilities to organize and perform activities required for fulfillment of teaching duties against a specific background."

Teacher efficacy has been defined as "the extent to which the teacher believes he or she has the capacity to affect student performance" (Berman, 
The Relationship among Iranian EFL Teachers' Professional Identity, Self-Efficacy and Critical Thinking Skills

McLaughlin, Bass, Pauly, \& Zellman, 1977, p. 137). Berman et al. (1977), in their study to evaluate 100 Elementary and Secondary Education Act teachers, found that "teachers' sense of efficacy emerged a powerful explanatory variable... Indeed the regression coefficient of the effects of a sense of efficacy [is] among the strongest relationships identified in our analysis" (p. 136).

Woolfolk and Hoy (1990) stated that researchers have found few constant relationships between teachers' characteristics and students' behavior or learning. Teachers' sense of efficacy is an exception to this general rule (p. 81). Gibson and Dembo (1984), in one of the first studies aimed at attempting to measure the dimensions of teacher self-efficacy, stated that by applying Bandura's theory to the construct of teacher efficacy, outcome expectancy would essentially show the degree to which teachers believed the environment could be controlled (Gibson \& Dembo, 1984, p. 570). Additionally, Ross (1994) investigated teacher efficacy studies in pre-college settings and identified a significant relationship between teachers' sense of efficacy and their behaviors. Soodak and Podell (1993) defined teacher efficacy as the conviction that one can successfully bring about the desired outcomes in one's students; that is, confidence in one's teaching abilities. Then, teacher self-efficacy beliefs can predict their effort and persistence in encountering difficulties and keeping students on task.

Critical thinking skills. The influences of critical thinking on human life, especially concerning education, cannot be ignored by teachers and researchers. The Educational Policy and Accreditation Standards (EPAS) states that: "critical thinking is self-directed thinking and a self-monitored process that requires effective problem solving abilities" (as cited in Colby, 2009, p. 121). According to Paul and Elder (2005), the four main reasons why critical thinking is becoming more important are: speeding up changes, increasing complexity, having more interdependence, and expanding danger. Facione (2009) argues that critical thinking skills are the "cornerstone of higher education" (p. 5). Unrau (1997) defines critical thinking as "a process of reasoned reflection on the meaning of claims about what to believe or what to do" (p. 14). The main features of critical thinking are: defining assumptions, focusing on uncertainties, analyzing discussions, asking and answering questions and evaluating the reliability of sources (Anderson et al., as cited in Emir, 2009). 
Negar Moslemi and

Parya Habibi

Branch (as cited in Seferoglu \& Akbiylk, 2006) stated that good critical thinkers are those who are inquisitive, open minded, proficient, analytical, scholarly, mature, self-confident, and seekers of truth. According to Carroll (2005), an excellent critical thinker is (1) curious and insightful, (2) perceptive and open-minded, (3) flexible, (3) fair-minded in evaluation, (4) fair in confronting individual needs and inclinations, (5) judicious in making judgments, (6) willing to reconsider and is clear on issues, (7) well-regulated in issues, (8) well-organized in seeking relevant information and seeking precise results, and (9) reasonable in the selection of criteria. Thinking skills including reasoning, problem solving, decision making, and creative thinking are considered the skills of great importance in social and educational contexts (Collier, Guenther, \& Veerman, 2002). Therefore, schools need to concentrate on how to think rather than what to think.

\section{Method}

This study explores the relationship among EFL teachers' professional identity, their efficacy, and their critical thinking skills. In order to achieve the objective of the present study, a survey was conducted among Iranian EFL teachers.

Participants. In the present study, the participants were EFL teachers teaching English as a foreign language in private language institutes of Iran. In selecting the main participants, availability sampling was used. The participants consisted of 90 experienced English language teachers holding a BA, an MA, or a PhD degree in TEFL, English literature, linguistics, or English translation. Out of the 90 teachers who participated in this study, 15 teachers were selected to take part in a pilot study on the questionnaires. Out of the

11475 participants who completed the questionnaires, $51(68 \%)$ of them, were females and the remaining $24(32 \%)$ were males; the majority of them were below 30 years of age.

Instruments. In the present study, the researchers used the Professional Identity questionnaire, Teachers' Efficacy Beliefs System-Self Form (TEBS-Self) questionnaire, and the Watson $\square$ Glaser Critical Thinking Appraisal test. Prior to the study, the three questionnaires were piloted with a group of $15 \mathrm{EFL}$ 
teachers. The purpose behind piloting the questionnaire was to estimate their reliability. The reliability index estimated through Cronbach's Alpha showed acceptable values:

Table 1. Reliability Statistics of the Questionnaires

\begin{tabular}{lcc}
\hline & N of Items & $\begin{array}{c}\text { Cronbach's Alpha } \\
\text { coefficient }\end{array}$ \\
\hline Professional identity questionnaire & 14 & 0.765 \\
\hline Teachers' self-efficacy beliefs & 31 & 0.15 \\
\hline Critical thinking appraisal questionnaire & & 0.76 \\
\hline
\end{tabular}

Beijaard professional questionnaire. This Beijaard Professional questionnaire was used to investigate teachers' professional identity. This questionnaire is modified based on the sets of professional identities questions used by Beijaard, Verloop, and Vermunt (2000). The questionnaire consisted of two parts; the first part contains questions about demographic aspects such as teachers' gender, age, and years of experience. The second part subsumes 14 items, which are categorized in three sub-scales including: subject matter knowledge and skills (items 1-4); didactical field (items 5-10) to express to what extent their teaching was based on knowledge and skills regarding the planning, execution, and evaluation of teaching and learning processes; and pedagogical field (items 11-14) to describe how much they base their teaching on knowledge and skills to support students' social, emotional, and moral development. This instrument uses a five-point scale, including: $1=$ never, $2=$ rarely, $3=$ sometimes, $4=$ often, $5=$ always.

Teachers' Efficacy Beliefs System-Self Form (TEBS-Self). Dellinger, Bobbett, Dianne, and Chad's (2008) Teachers' Efficacy Beliefs System-Self form (TEBS-Self) was used to assess teachers' self-efficacy beliefs about their own abilities to successfully perform specific teaching (Appendix I). The TEBS-Self subsumes 31 items, which are categorized in six sub-scales with some of the items falling within two or more categories including: communication/clarification (items 9, 5, 10, 11, 15, 16, 17, 18, 22, 23); management/climate (items 3, $4,5,6,7,8,9,10,24,30,31$ ); accommodating individual differences (items 1 , 
Negar Moslemi and

Parya Habibi

$2,7,12,13,14,27,28)$; motivation of students (items 3, 26, 29, 30); managing learning routines (items 3, 4, 5); and higher-order thinking skills (items 4, 19, $20,21,25)$. This instrument uses a five-point scale, namely: $1=$ very weak, $2=$ weak, $3=$ moderate, $4=$ strong, $5=$ very strong.

This questionnaire is used by the researchers in various contexts to measure teachers' self-efficacy beliefs about their own abilities.

The Watson-Glaser Critical Thinking Appraisal questionnaire. The Watson-Glaser Critical Thinking Appraisal is an assessment tool designed to measure an individual's critical thinking skills. It is used to determine an individual's ability to think critically and to assess their suitability for an organization or a specific position within it (Appendix V). The test comprises five sections: 1) Inferences; 2) Assumptions; 3) Deductions; 4) Interpreting Information; and 5) Arguments. The participants read the instructions preceding each section and answer the questions. There are a total of 85 questions in this test and they should aim to correctly answer as many questions as they can within 40 minutes.

Procedure. During the 2017-2018 academic year, the three questionnaires were distributed to the participants at the institutions participating in this study and were completed at the time of distribution. Detailed instructions were given by the researcher on how to complete the questionnaires. While distributing the questionnaire, the researchers informed the participants of the goals and importance of the study. They were also asked to present their true and honest responses. On average, it took each respondent around 65 minutes to read and answer the items.

Data analysis. To analyze the data, teachers' responses to the items of the questionnaires were fed into SPPS (version 21). In order to investigate the relationship between teachers' professional identity, self-efficacy, and their critical 116 thinking skills, the data were analyzed quantitatively using Pearson Correlation. To analyze the data for the second and fourth research questions, simple linear regression, whose significance is shown through ANOVA, was run.

\section{Results}

This part presents the results of the data analyses in order to provide answers to the above questions. 
The Relationship among Iranian EFL Teachers' Professional Identity, Self-Efficacy and Critical Thinking Skills

Demographic information. Table 2 below shows the information related to the participants' demographic characteristics.

Table 2. Participants' Demographic Information Statistics

\begin{tabular}{|c|c|c|c|c|}
\hline & Frequency & Percent & Valid Percent & $\begin{array}{c}\text { Cumulative } \\
\text { Percent }\end{array}$ \\
\hline \multicolumn{5}{|l|}{ Gender } \\
\hline Male & 24 & 32.0 & 32.0 & \multirow{3}{*}{$\begin{array}{c}32.0 \\
100.0\end{array}$} \\
\hline Valid Female & 51 & 68.0 & 68.0 & \\
\hline Total & 75 & 100.0 & 100.0 & \\
\hline \multicolumn{5}{|l|}{ Degree } \\
\hline $\mathrm{BA}$ & 15 & 20.0 & 20.0 & \multirow{4}{*}{$\begin{array}{c}20.0 \\
94.0 \\
100.0\end{array}$} \\
\hline MA & 56 & 74.7 & 74.7 & \\
\hline Valid PhD & 4 & 5.3 & 5.3 & \\
\hline Total & 75 & 100.0 & 100.0 & \\
\hline \multicolumn{5}{|l|}{ Major } \\
\hline English Translation & 14 & 18.7 & 18.7 & \multirow{5}{*}{$\begin{array}{c}18.7 \\
86.7 \\
96.0 \\
100.0\end{array}$} \\
\hline TEFL & 51 & 68.0 & 68.0 & \\
\hline Valid English Literature & 7 & 9.3 & 9.3 & \\
\hline Linguistics & 3 & 4.0 & 4.0 & \\
\hline Total & 75 & 100.0 & 100.0 & \\
\hline \multicolumn{5}{|l|}{ Age } \\
\hline Below 30 & 36 & 48.0 & 48.0 & \multirow{5}{*}{$\begin{array}{c}48.0 \\
86.0 \\
93.3 \\
100.0\end{array}$} \\
\hline $31-35$ & 29 & 38.7 & 38.7 & \\
\hline Valid $\quad 36-40$ & 5 & 6.7 & 6.7 & \\
\hline Upper 41 & 5 & 6.7 & 6.7 & \\
\hline Total & 75 & 100.0 & 100.0 & \\
\hline
\end{tabular}

Table 2 indicates the information related to the respondents' gender, academic degree, major, and age. From the total of 75 respondents, 24 were male and 51 were female. As shown in Table 2, from the total of the 75 teachers, 15 had a $\mathrm{BA}, 56$ had an MA, and 4 participants had a $\mathrm{PhD}$. And most of the respondents' major in education was TEFL. The information related to participants' age is 
Negar Moslemi and

Parya Habibi

presented in this table as well. Out of the total of 75 respondents in the study, most of the respondents' age was below 30.

\section{Research questions}

Q1: Is there a relationship between EFL teachers' professional identity and their self-efficacy?

Table 3. The descriptive statistics of EFL teachers' professional identity and their self-efficacy

\begin{tabular}{lclc}
\hline & Mean & Std. Deviation & N \\
\hline Teachers' Efficacy & 137.12 & 8.261 & 75 \\
Teachers' Professional Identity & 57.65 & 3.607 & 75 \\
\hline
\end{tabular}

The relationship between EFL teachers' professional identity and selfefficacy was analyzed by Pearson correlation coefficient.

Table 4. Pearson Correlation; Self-Efficacy with Professional Identity

\begin{tabular}{llcc}
\hline & Pearson Correlation & $\begin{array}{c}\text { Teachers' } \\
\text { Efficacy }\end{array}$ & $\begin{array}{c}\text { Teachers' } \\
\text { Professional } \\
\text { Identity }\end{array}$ \\
\hline Teachers' Efficacy & Sig. (2-tailed) & 1 & $.443^{* *}$ \\
& $\mathrm{~N}$ & 75 & .000 \\
\hline Teachers' & Pearson Correlation & $.443^{* *}$ & 75 \\
Professional & Sig. (2-tailed) & .000 & 1 \\
Identity & $\mathrm{N}$ & 75 & 75 \\
\hline
\end{tabular}

** Correlation is significant at the 0.01 level (2-tailed).

The obtained results showed positive correlation between the two variables $(\mathrm{P}</ 000$ and $\mathrm{r}=0 / 443, \mathrm{n}=75)$. The positive relationships between 
The Relationship among Iranian EFL Teachers' Professional Identity, Self-Efficacy and Critical Thinking Skills

two variables indicate that, as EFL teachers' professional identity increases, the level of EFL teachers' self-efficacy increases too.

Q2. Does EFL teachers' professional identity significantly predict their self-efficacy? A simple linear regression was run to predict EFL teachers' self-efficacy through their professional identity. As shown in Table 5, the EFL teachers' professional identity predicted 19.6 percent of their self-efficacy $\left(\mathrm{R}=.443, \mathrm{R}^{2}=.196\right)$.

Table 5. Model Summaryb: Predicting EFL Teachers' Self-Efficacy through

\begin{tabular}{ccccc}
\hline Model & $\mathbf{R}$ & R Square & $\begin{array}{c}\text { Adjusted } \mathbf{R} \\
\text { Square }\end{array}$ & $\begin{array}{c}\text { Std. Error } \\
\text { of the Estimate }\end{array}$ \\
\hline 1 & $.443^{\mathrm{a}}$ & .196 & .185 & 7.458 \\
\hline
\end{tabular}

a. Predictors: (Constant), teachers' Professional Identity

b. Dependent Variable: Teachers' Efficacy

The results of the ANOVA test of significance of the regression model ( $\mathrm{F}$ $(1,73)=17.788, \mathrm{p}=.000)$ indicated that the regression model was significant. That is to say, EFL teachers' professional identity could predict their self-efficacy.

Table 6. ANOVAa Test of Significance of Regression Model

\begin{tabular}{llccccc}
\hline \multicolumn{1}{l}{ Model } & Sum of Squares & Df & Mean Square & F & Sig. \\
\hline \multirow{3}{*}{$\begin{array}{l}\text { 1 } \\
\text { Regression }\end{array}$} & Residual & 989.432 & 1 & 989.432 & 17.788 & $.000^{\mathrm{b}}$ \\
\cline { 2 - 5 } & Total & 5060.488 & 73 & 55.623 & & \\
\hline
\end{tabular}

a. Dependent Variable: Teachers' Efficacy

b. Predictors: (Constant), teachers' Professional Identity

The results of Table 7 can be used to build the regression equations as:

Self-Efficacy $=$ Constant $+(\mathrm{b} *$ professional Identity $)$

Self-Efficacy $=78.680+(0.240 *$ professional Identity $)$ 
Negar Moslemi and

Parya Habibi

Table 7. Coefficientsa ; Predicting EFL Teachers' Self-Efficacy through Professional Identity

\begin{tabular}{|c|c|c|c|c|c|c|c|c|}
\hline & \multirow{2}{*}{$\begin{array}{c}\text { Model } \\
\text { B }\end{array}$} & \multicolumn{2}{|c|}{$\begin{array}{l}\text { Unstandardized } \\
\text { Coefficients }\end{array}$} & \multirow[t]{2}{*}{$\begin{array}{c}\text { Standardized } \\
\text { Coefficients }\end{array}$} & \multirow[t]{2}{*}{$\mathbf{t}$} & \multirow[t]{2}{*}{ Sig. } & \multicolumn{2}{|c|}{$\begin{array}{c}95.0 \% \\
\text { Confidence } \\
\text { Interval for B }\end{array}$} \\
\hline & & $\begin{array}{l}\text { Std. } \\
\text { Error }\end{array}$ & Beta & & & & $\begin{array}{l}\text { Lower } \\
\text { Bound }\end{array}$ & $\begin{array}{l}\text { Upper } \\
\text { Bound }\end{array}$ \\
\hline & (Constant) & 78.680 & 13.883 & & 5.667 & .000 & 51.012 & 106.349 \\
\hline 1 & $\begin{array}{l}\text { Teachers' } \\
\text { Professional } \\
\text { Identity }\end{array}$ & 1.014 & .240 & .443 & 4.218 & .000 & .535 & 1.493 \\
\hline
\end{tabular}

a. Dependent Variable: Teachers' Efficacy

Q3. Is there any relationship between Iranian English language teachers' professional identity and their critical thinking skills?

Table 8. The Descriptive Statistics of EFL Teachers' Professional Identity and

\begin{tabular}{|c|c|c|c|}
\hline \multicolumn{4}{|c|}{ Their Self-Efficacy } \\
\hline & Mean & Std. Deviation & $\mathbf{N}$ \\
\hline 'Teachers' critical thinking & 72.76 & 5.514 & 75 \\
\hline 'Teachers' Professional Identity & 57.65 & 3.607 & 75 \\
\hline
\end{tabular}

120 In order to answer the third research question, the researcher could use Pearson correlation coefficient. 
The Relationship among Iranian EFL Teachers' Professional Identity, Self-Efficacy and Critical Thinking Skills

Table 9. Pearson Correlation; Critical Thinking Skills with Professional Identity

\begin{tabular}{llcc}
\hline & & $\begin{array}{c}\text { Teachers' } \\
\text { critical thinking } \\
\text { skills }\end{array}$ & $\begin{array}{c}\text { Teachers' } \\
\text { Professional } \\
\text { Identity }\end{array}$ \\
\hline Teachers' critical & Pearson Correlation & 1 & $.388^{* *}$ \\
thinking skills & Sig. (2-tailed) & $\mathrm{N}$ & .001 \\
Teachers' & Pearson Correlation & $.388^{* *}$ & 75 \\
Professional & Sig. (2-tailed) & .001 & 1 \\
Identity & $\mathrm{N}$ & 75 & 75 \\
\hline
\end{tabular}

** Correlation is significant at the 0.01 level (2-tailed).

The obtained results showed a positive correlation between the two variables $(\mathrm{P}</ 001$ and $\mathrm{r}=0 / 388, \mathrm{n}=75)$. The positive relationships between these two variables indicate that, as EFL teachers' professional identity increases, the level of EFL teachers' critical thinking skills increases too.

Q4. Does EFL teachers' professional identity significantly predict their critical thinking skills? In order to answer the forth research question, the researcher could also use simple linear regression to predict EFL teachers' critical thinking skills through their professional identity. As shown in Table 10; the EFL teachers' professional identity predicted 15.0 percent of their critical thinking skills $\left(\mathrm{R}=.388, \mathrm{R}^{2}=.150\right)$.

Table 10. Model Summary: Predicting EFL Teachers' Critical Thinking Skills

\begin{tabular}{ccccc}
\hline Model & $\mathbf{R}$ & R Square & $\begin{array}{c}\text { Adjusted } \mathbf{R} \\
\text { Square }\end{array}$ & $\begin{array}{c}\text { Std. Error } \\
\text { of the Estimate }\end{array}$ \\
\hline 1 & $.388^{\mathrm{a}}$ & .150 & .139 & 5.117 \\
\hline
\end{tabular}

a. Predictors: (Constant), Teachers' Professional Identity

b. Dependent Variable: Teachers' critical thinking 
Negar Moslemi and

Parya Habibi

The results of the ANOVA test of significance of the regression model $(\mathrm{F}(1,73)=12.920, \mathrm{p}=.001)$ indicated that the regression model was significant. That is to say that EFL teachers' professional identity could predict their critical thinking skills.

Table 11. ANOVAa Test of Significance of Regression Model

\begin{tabular}{llccccc}
\hline & Model & Sum of Squares & Df & Mean Square & F & Sig. \\
\hline & Regression & 338.288 & 1 & 338.288 & 12.920 & $.001^{\text {b }}$ \\
1 & Residual & 1911.392 & 73 & 26.183 & & \\
& Total & 2249.680 & 74 & & & \\
\hline
\end{tabular}

a. Dependent Variable: Teachers' critical thinking skills

b. Predictors: (Constant), Teachers' Professional Identity

The results of Table 12 can be used to build the regression equations as:

Critical thinking skills $=$ Constant $+(\mathrm{b} *$ professional Identity $)$

Critical thinking skills $=35.589+(0.593 *$ professional Identity $)$

Table 12. Coefficientsa: Predicting EFL Teachers' Crit ical Thinking Skills through Professional Identity

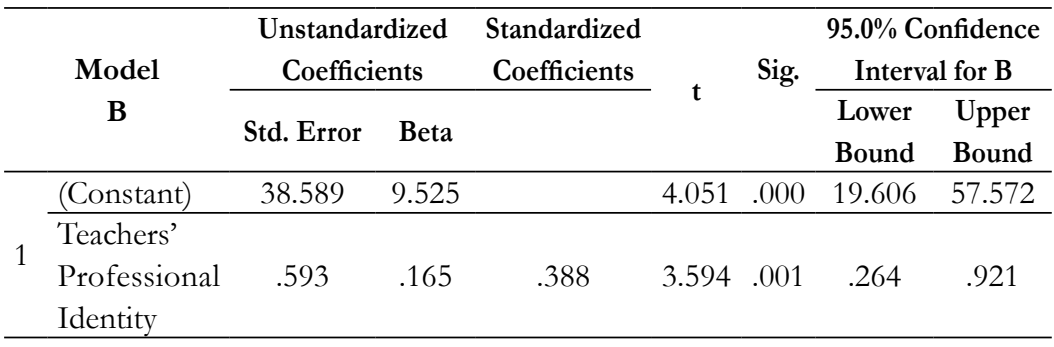

a. Dependent Variable: Teachers' critical thinking skills

We are $95 \%$ confident that the slope of the true regression line is somewhere between .264 and .921 . In other words, we are $95 \%$ confident that teachers' professional identity can predict their critical thinking skills somewhere between .264 and .921 . 
The Relationship among Iranian EFL Teachers' Professional Identity, Self-Efficacy and Critical Thinking Skills

\section{Discussion}

In the present study, the main objective was to investigate the relationship between English language teachers' professional identity, their efficacy, and their critical thinking skills. In response to the first research question, the results obtained in this study confirmed a relationship between English language teachers' professional identity and their efficacy. The positive relationship between the two variables indicates that as EFL teachers' professional identity increases, the level of their self-efficacy increases too. As for the second research question, the results indicated that EFL teachers' professional identity could predict their self-efficacy. The findings are in line with Bandura (1998), TschannenMoran and Hoy (2001), and Volkmann and Anderson (1998). Bandura (1998) interpreted that an individual's profession presents a significant reference of personal identity, and self-worth and self-efficacy beliefs play an important role in career development. Tschannen-Moran and Hoy (2001) believed that teacher efficacy is related to some meaningful educational issues including teachers' persistence, enthusiasm, commitment, and instructional behavior, as well as student issues such as achievement, motivation, and self-efficacy beliefs. Volkmann and Anderson (1998) maintained that professional identity is a complex and active equilibrium where personal self-image is assessed with a variety of social roles that teachers feel obliged to play.

In response to the third question, the results confirmed a relationship between English language teachers' professional identity and their critical thinking skills. The positive relationships between these two variables indicate that, as EFL teachers' professional identity increases, the level of their critical thinking skills increases too. As for the fourth question, the results indicated that EFL teachers' professional identity could predict their critical thinking skills. The findings are in line with Ruminski and Hanks (1995). Halvorsen (2005) defines critical thinking as, "To think critically about an issue is to consider that issue from various perspectives, to look at and challenge any possible assumptions that may underlie the issue and to explore its possible alternative" (p. 1). Ruminski and Hanks (1995) believe teachers should have an astute concept of critical thinking before they commence teaching and evaluating.

The value of the findings of the present study lies in the fact that almost all the claims related to the prediction of teacher professional identity about 
Negar Moslemi and

Parya Habibi

their self-efficacy and their critical thinking skills have been theoretical and this study sheds empirical light on the issue. Thus, the results of the study imply that pre-service and even in-service teachers should familiarize themselves with the influence of professional identity and their other personal identities on their teaching process. The essential quality inherent in the two variables is a desire to teach well. As is evident, upon dissecting the three variables, they all have qualities which aim at a common goal, that is, the better presentation of opportunities for teacher development.

\section{Conclusions and Implications}

In traditional (or formal) education, teachers are the most important influences concerning student achievement. EFL teachers can improve their own teaching by deliberately and analytically concentrating on their personal identities during their teaching process. Professional identity as a part of teachers' identity can affect the other language teachers' personal characteristics such as their efficacy and their critical thinking skills. The role of teachers' perceptions, beliefs, identities, and efficacy in making EFL instruction effective, and also in improving their performance to enhance students' learning can be helpful. Beijaard, Meijer, and Verloop (2004) believe that research on teachers' professional identity focuses on the ways "teachers relate to other people, and the responsibilities, attitudes, and behaviors they adopt as well as the knowledge they use" (p. 125). Teachers' awareness of their identities, self-efficacy, and critical thinking skills, which can be considered as important factors in professional development, can also be helpful in their general development. In conclusion, teachers' individual professional identity was concentrated on their self-efficacy and critical thinking skills. The findings of the present study demonstrate that EFL teachers' self-efficacy and their

124 critical thinking skills increase as their professional identity increases.

Professional identity as one of the language teachers' personal features can affect their other personal characteristics. In the present study, the researchers wanted to consider professional identity as a predictor of EFL teachers' selfefficacy. The findings in the present study demonstrated that there is a positive relationship between EFL teachers' professional identity and other variables. However, due to some important limitations, the results of this study need to 
The Relationship among Iranian EFL Teachers' Professional Identity, Self-Efficacy and Critical Thinking Skills

be interpreted cautiously. First, the study was based on correlational data, and second, the number of participants was limited.

The findings are interpreted to have pedagogical implications for students, language teachers, curriculum developers, and those who took part in the study. These findings can be helpful in teacher development where teacher identity, self-efficacy, and critical thinking skills are considered as important factors in professional development.

The present study set out to investigate the relationship between EFL teachers' professional identity, their self-efficacy, and critical thinking. However, much remains to be done in this field such as: the functions of different personal characteristics in EFL teachers' professional identity and the difference between EFL experienced and inexperienced teachers' professional identity and their efficacy.

\section{References}

Bandura, A. (1986). Social foundations of thought and action: A social cognitive theory. NJ: Prentice-Hall.

Bandura, A. (1997). Self-efficacy: The exercise of control. New York: W. H. Freeman and Company.

Bandura, A. (1998). Insight: Self-efficacy. HarvardMental Health Letter, 13(9), 4-6.

Beijaard, D., Meijer, P.C., \& Verloop, N. (2004). Reconsidering research on teachers' professional identity. Teaching and Teacher Education, 20, 107-128.

Beijaard, D., Verloop, N., \& Vermunt, J. D. (2000). Teachers' perception of professional identity: an exploratory study from a personal knowledge perspective. Teaching and Teacher Education, 16(7), 749-764.

Berman, P., M. McLaughlin, G. Bass, E. Pauly, \& G. Zellman. (1977). Federal

Programs Supporting Educational Change (Vol.7): Factors Affecting Implementation and Continuation. Santa Monica, California: Rand Corporation.

Borg, S. (2003). Teacher cognition in language teaching: A review of research on what language teachers think, know, believe, and do. Language teaching, 36(2), 81-109.

Brown, H. D. (2001). Teaching by Principles. New York: Longman. 
Negar Moslemi and

Parya Habibi

Carroll, R. T. (2005). Teacbing critical thinking. The Amazing Meeting in Las Vegas.

Colby, I. (2009). An overview of social work education in the United States: New directions and new opportunities. China Journal of Social Work, 2(2), 119-130.

Collier, K., Guenther, T., \& Veerman, C. (2002). Developing critical thinking skills through a variety of instructional strategies. An action research project submitted to the Graduate Faculty of the School of Education as requirement of the degree of Masters of Arts in Teaching and Leadership. Saint-Xavier University. Chicago, Illinois.

Dellinger, A., Bobbett, J., Dianne, F. O., \& Chad, O. (2008). Measuring teachers' self-efficacy beliefs: development and use of the TEBS-Self. Teaching and Teacher Education, 24, 751-766. Doi:10.1016/j.tate.2007. 02.010.

Emir, S. (2009). Education faculty students' critical thinking disposition according to academic achievement. Procedia Social and Behavioral Sciences, 1(1), 2466- 2469.

Facione, P. A. (2009). Critical thinking. CA: The California Academic Press.

Farrell, T. S. (2008). Reflective practice in the professional development of teachers of adult English language learners. Retrieved February 9, 2011, from: http:/ /www.cal. org/caelanetwork/pd_resources/reflectivepracticefinalweb.pdf

Ghafar Samar, R., Kiany, G. R., Akbari, R., \& Azimi, H. (2011). Institutional identity of teachers: A determinant of teacher efficacy. TELL, 5(2), 31-59.

Gibson, S., \& Dembo, M. H. (1984). Teacher Efficacy: A construct validation. Journal of Educational Psychology. 76, 569-582.

Giddens, A. (2002). Runaway World: How globalization is reshaping our lives. New York: Routledge.

126 Golombek, P. R., \& Johnson, K. E. (2004). Narrative inquiry as a mediation space: examining emotional and cognitive dissonance in second-language teachers' development. Teachers and Teaching, 10, 307-327.

Halvorsen, A. (2005). Incorporating critical thinking skills development into ESL/ EFL courses. The Internet TESL Journal, 11(3), 1-5.

Helleve, A., Flisher, A., Onya, H., Mukkoma, W., \& Klepp, K. (2009). South African Teachers' reflections on the impact of culture on their teaching of sexuality and HIV/AIDS. Culture, Health \& Sexuality, 11(2), 189-204. 
The Relationship among Iranian EFL Teachers' Professional Identity, Self-Efficacy and Critical Thinking Skills

Kearney, C. (2003). The Monkey's Mask: identity, memory, narrative and voice. Language teachers think, know, believe, and do. Language Teaching, 36(2), 81-109.

Little, D. (1995). Learning as dialogue: The dependence of learner autonomy on teacher autonomy. System, 23(2), 175-182.

Maddux, J. E. (1995). Looking for common ground: a comment on Kirsch and Bandura. In J. E. Maddux (Ed.), Self-efficacy, adaptation and adjustment: theory, research, and application (pp. 377-386). New York: Plenum McGraw Hill.

McPeck, J. E. (1981). Critical thinking in education. New York: St. Martin’s Press.

Morita, N. (2004). Negotiating participation and identity in second language academic communities. TESOL Quarterly, 38(4), 573-603.

Nishino, T. (2009). Communicative language teaching in Japanese bigh schools: Teachers' beliefs and classroom practices. Unpublished doctoral dissertation, Temple University, Philadelphia, PA.

Pajares, F. (1996). Assessing self-efficacy beliefs and academic success: The Case for specificity and correspondence. Paper presented at the Annual Meeting of the American Educational Research Association, New York.

Palmer, P. J. (1998). The courage to teach: Exploring the inner landscape of a teacher's life. San Francisco, CA: Jossey-Bass Publishers.

Paul, R., \& Elder, L. (2005). A guide for educators to critical thinking competency standards. CA: Foundation for Critical Thinking.

Pintrich, P. R., \& D. H. Schunk. (1995). Motivation in education: Theory, research, and applications. NJ: Prentice Hall.

Rich, Y., Lev, S., \& Fischer, S. (1996). Extending the concept and assessment of teacher efficacy. Educational and Psychological Measurement, 56(6), 1015-1025.

Ross, J. A. (1994). Beliefs that make a difference: The origins and impacts of teacher efficacy. Paper presented at the annual meeting of the Canadian Association for Curriculum Studies.

Ruminski, H. J., \& Hanks, W. E. (1995). Critical thinking lacks definition and uniform evaluation criteria. Journalism and Mass Education Educator, 50(3): 4-11. 
Negar Moslemi and

Parya Habibi

Schwitzgebel, E. (2011). Belief. (E. N. Zalta, Editor) Retrieved from The Stanford Encyclopedia of Philosophy: http://plato.stanford.edu/archives/ win2011/entries/belief/.

Seferolu, S., \& Akbiyık, C. (2006). Elestirel düünme ve ogretimi. H. U. Egitim Fakeültesi Dergisi (H.U. Journal of Education). 30, 193-200.

Smith, E. P., Walker, K., Fields, L., Brookins, C. C., \& Seay, R. C. (1999). Ethnic identity and its relationship to self-esteem, perceived efficacy and prosocial attitudes in early adolescence. Journal of Adolescence, 22, 867-880.

Soodak, L. C., \& Podell, D. M. (1993). Teacher efficacy and student problem as factors in special education referral. Journal of Special Education, 27, 1, 66-81.

Tschannen-Moran, M. \& Hoy, A. W. (2001). Teacher efficacy: capturing an elusive construct. Teaching and Teacher Education. 17(7), 783-805.

Tschannen-Moran, M., \& Hoy, A. W. (2007). The differential antecedents of self-efficacy beliefs of novice and experienced teachers. Teaching and Teacher Education. 23, 944-956.

Tschannen-Moran, M., Woolfolk Hoy, A., \& Hoy, W. K. (1998). Teacher efficacy: Its meaning and measure. Review of Educational Research, 68, 202-248.

Unrau, J. N. (1997). Thoughtful teachers, thoughtful learners: A guide to helping adolescents think critically. Ontario: Pippin Publishing Corporation.

Volkmann, M. J., \& Anderson, M. A. (1998). Creating professional identity: Dilemmas and metaphors of a first-year chemistry teacher. Science Education, 82(3), 293-310.

White, J. L., \& Parham, T. A. (1990). The psychology of Blacks: An African American Perspective (2 ${ }^{\text {nd }}$ ed.). NJ: Prentice Hall.

Williams, R. L. (2005). Targeting critical thinking within teacher education: The potential impact on society. The Teacher Educator, 40(3), 163-187.

Woods, D. (1991). Teachers' interpretations of second language teaching curricula. RELC Journal, 22, 1-19.

Woolfolk, A. E., \& Hoy, W. K. (1990). Prospective teachers' sense of efficacy and beliefs about control. Journal of Educational Psychology, 82, 81-91. 